Оригинални научни рад

Tamás Nótári, Ph.D., Associate Professor

University of Szeged

Faculty of Law and Political Sciences

\title{
LAW OF CONTRACTS IN LEX BAIUVARIORUM ${ }^{l}$
}

Abstract: This paper intends to analyse the contractual provisions of Lex Baiuvariorum, ${ }^{2}$ the written Bavarian Volksrecht ${ }^{3}$ created between 737 and 743. As part of that, first, it will examine the required formalities of entering into a contract, documentary evidence and testimony (I.), then the issues of invalidity (II.), implied warranty and buying stolen things (III.), regulation of contractual safeguards (IV.), finally, other contracts touched upon in the code (V.). Concerning sedes materiae it should be stated in advance that provisions regarding exchange of goods can be found primarily in two titles of the code: title eleven (De venditionibus) and title nine (De furto)-the latter sets out the rules on selling stolen things, i.e., implied warranty claims, which pay regard to the rela-

${ }^{1}$ The present paper was supported by the TÁMOP Project Nr. 4.2.2.B-10/1-2010-0015 „Identitäten: Kulturen und Minderheiten im Donauraum“.

${ }^{2}$ On Lex Baiuvariorum see Nótári, T.: Lex Baiuvariorum-A bajorok törvénye. Szeged 2011. (Nótári 2011a); Römischrechtliche Elemente im Prolog der Lex Baiuvariorum. Annales Universitatis Scientiarum Budapestinensis de Rolando Eötvös nominatae, Sectio Iuridica 50. 2009. 419-429; Bavarian Historiography in Early Medieval Salzburg. Passau 2010; Personal Status and Social Structure in Early Medieval Bavaria. Acta Juridica Hungarica 50. 2009/1. 85110; An Early-Medieval „Show Trial”-Tasilo III's Dethronement. In: Beck Varela, L.-Gutiérrez Vega, P.-Spinosa, A. (eds): Crossing Legal Cultures. München 2009. 141-158.

${ }^{3}$ Cf. Beyerle, K.: Lex Baiuvariorum. Lichtdruckwiedergabe der Ingolstädter Handschrift. München 1926; Merkel, J.: Das Bairische Volksrecht. Archiv der Gesellschaft für ältere deutsche Geschichtskunde 11. 1858. 533-687; Schwind, E. v.: Kritische Studien zur Lex Baiuwariorum III. Neues Archiv der Gesellschaft für ältere deutsche Geschichtskunde 37. 1912. 415-451; Krusch, B.: Die Lex Bajuvariorum. Berlin 1924. 38-163; Kottje, R.: Die Lex Baiuvariorum-das Recht der Baiern. In: Mordek, H. (Hrsg.): Überlieferung und Geltung normativer Texte des frühen und hohen Mittelalters. Sigmaringen 1986. 9-23; Eckhardt, K. A.: Die Lex Baiuvariorum. Eine textkritische Studie. Untersuchungen zur deutschen Staats- und Rechtsgeschichte 38. Bresslau 1927; Landau, P.: Die Lex Baiuvariorum: Entstehungszeit, Entstehungsort und Charakter von Bayerns ältester Rechts- und Geschichtsquelle. München 2004. 
tion between the person who has been robbed and the person who buys the thing in good faith, on the one hand, and between seller and buyer, on the other. ${ }^{4}$ Certain provisions, for example, regarding prohibition to sell things in action can be found in title fifteen (De commendatis et commodatis).

Key words: Lex Baiuvariorum, Bavarian Volksrecht, Bavarian Contract Law

\section{Required formalities of the contract - documentary evidence and testimony}

First, it is worth examining what required formalities apply to entering into contract in early medieval Bavarian law. This scope of issues is provided for under two loci in the code. ${ }^{5}$

"Si quis vendiderit possessionem suam alicui, terram cultam, non cultam, prata vel silvas, post accepto pretio aut per cartam aut per testes conprobetur firma emptio. Ille testis per aurem debet esse tractus, quia sic habet lex vestra; duo vel tres debent esse. Venditio si fuerit violenter extorta, id est aut metu mortis aut per custodiam, nulla ratione firma sit. "6 In accordance with the first one, when somebody sells his immovable property to somebody else-here cultivated or uncultivated land, meadows and forests are listed as examples-purchase will be considered valid after payment of the price by issuance of the charter and production of evidence by witnesses. Witnesses' ears must be pulled in accordance with the provision of the code, and at least two or three witnesses are required for valid production of evidence. The phrase "post accepto pretio" clearly shows that the transaction is entered into by handing over the purchase price as-without presuming borrowing-Iustinianus also renewed the provision of the Twelve Table Law (no longer existing in classical law) stating that the buyer will obtain the ownership of the goods once he has paid the total price or has given security for it. $^{7}$

This provision is meant to ensure community control of conclusion of contract and thereby intends to exclude the possibility of coercion from exchange of properties. ${ }^{8}$ Another locus is fully in harmony with this rule: it sets forth that no matter that the subject of purchase constitutes servants or land or houses or fo-

\footnotetext{
${ }^{4}$ Babják I.: Barbárság vagy germánság? Árucsere Európa hajnalán. Budapest 2011. 175.

${ }^{5}$ Lex Baiuvariorum 16, 2. 16.

${ }^{6}$ Lex Baiuvariorum 16, 2.

${ }^{7}$ Cf. Nótári T.: Római köz- és magánjog. Kolozsvár 2011. (Nótári 2011b) 314; Szűcs M.: A vételár kifizetése mint a tulajdonszerzés feltétele (Inst. 2,1,41), in: Római jog és a magánjog fejlődése Európában. Tanulmányok Molnár Imre 75. születésnapjára. Szerk. Jakab Éva, Szeged

${ }^{8}$ Babják 2011. 176.
} 2011. $201-221$. 
rests, it must be confirmed by a deed or witnesses for better provability. ${ }^{9}$ Pulling witnesses' ears as part of the procedure is mentioned in the title on witnesses (De testibus et eius causis) too. ${ }^{10}$ It should be noted that whereas this locus requires two or more witnesses for production of evidence, the locus to be cited below minimises the number of witnesses to three; ${ }^{11}$ yet, evidence of donations to the Church requires at least six witnesses. ${ }^{12}$ Therefore, the provision on the number of witnesses depends on the character of the transaction and the parties taking part in the transaction-for example, when the Church is involved as legal subject on one side.

"De pactis vel placitis. Pacta vel placita, quae per scriptura quacunque facta sunt, vel per testes denominatos III vel amplius, dummodo in his dies et annus sit evidenter expressus, inmutare nulla ratione sinere permittimus. "13 The provision that accepts the contracts and agreements that have been executed in written form or in the presence of three or more witnesses and bear the exact date, i.e., day and year, when they are entered into ${ }^{14}$ as unchangeable and valid shows clear correspondence with the provisions of the Visigothic, ${ }^{15}$ Langobardic $^{16}$ and Alemannian ${ }^{17}$ law. ${ }^{18}$ There are good chances that reference to witnesses reflects the practice of Bavarian unwritten law, the primacy of testimony; however, recording the exact date applies, as a matter of fact, to documentary evidence; regarding this provision Babják establishes that this is a rule adopted from post-classical Roman law ${ }^{19}$ through Visigothic mediation. ${ }^{20}$

Mayer-Maly, whom Babják agrees with, claims that the phrase "pacta vel placita" serves to ensure that pactums (additional agreements, in this respect

${ }^{9}$ Lex Baiuvariorum 16, 15. Quicquid vendiderit homo aut conparaverit, qualecumque re, omnia sint firmata aut per cartam aut per testes, qui hoc probare possent; hoc est de mancipiis, de terra, casas vel silvis, ut postea non sit contentio.

${ }^{10}$ Lex Baiuvariorum 17, 3. Si quis testem habuerit per aurem tractum de qualibet causa finita ratione, et hoc confirmant per testes; post haec non debet repetire nec inquietare illum, a quo finivit rationem suam.

${ }^{11}$ Lex Baiuvariorum 16, 16. Pacta vel placita, quae per scriptura quacunque facia sunt, vel per testes denominatos III vel amplius...

${ }^{12}$ Lex Baiuvariorum 1, 1. Et quicquid donaverit, villas terra mancipia vel aliqua pecunia, omnia quaecumque donaverit pro redemptione animae suae, hoc per epistulam confirmet propria manu sua ipse, et testes adhibeat VI vel amplius si voluerit...

${ }^{13}$ Lex Baiuvariorum 16, 16.

${ }^{14}$ See Brunner, H.: Zur Rechtsgeschichte der römischen und germanischen Urkunde. Berlin 1880.

${ }^{15}$ Cf. Lex Wisigothorum 2, 5, 2. 3.

${ }^{16}$ Cf. Leges Liutprandi 116.

${ }^{17}$ Cf. Lex Alamannorum Hlothariana 43.

${ }^{18}$ Nótári 2011a $96^{319}$.

${ }^{19}$ Codex Theodosianus 1, 1, 1.

${ }^{20}$ Babják 2011. 177. 
pacta adiecta) could be contested in legal action. ${ }^{21}$ In accordance with the rule on properties, to ensure validity-emphatically after payment of the purchase price-either a carta had to be issued or witnesses had to be used for demonstration, whereas pacta and placita served the sale of movable properties, and in this case payment of the purchase price could be separated in time from valid execution of the transaction. ${ }^{22}$ Regarding the former, the lawmaker might have wanted to attain that the buyer should be assured by witnesses, while regarding the latter, that the agreement could not be terminated or changed. ${ }^{23}$

\section{The issue of invalidity}

It is worth paying attention to the fact that with regard to proving execution of the transaction the law contains a material provision concerning validity that stipulates that in the event that sale has been forced by violence either by death threat or confinement, then it shall not be considered valid by any means: Venditio si fuerit violenter extorta, id est aut metu mortis aut per custodiam, nulla ratione firma sit. "24 This rule can be clearly considered a borrowing from Lex Wisigothorum as that code also sets forth unconditional invalidity or nullity of purchase forced by violence or intimidation. ${ }^{25}$ The relevant provision of the Visigothic Codex Euricianus literally corresponds to the Bavarian law as it also speaks about violence, death threat or confinement used to ensure conclusion of contract. ${ }^{26}$ Undoubtedly, this rule of Visigothic law goes back to the vis ac metus concept of Roman law: $:^{27}$ in Roman law direct, i.e., physical coercion (vis absoluta) resulted in nullity in developed law, whereas indirect coercion bending the will (vis compulsiva) resulted in contestability. ${ }^{28}$ Babják establishes it correctly that in Roman law vis ac metus appears as an abstract category, however, Lex Baiuvariorum-and Visigothic regulation, as no other Volksrecht contains invalidity causes-grasps this defective intention by naming two particular conducts: death threat (metu mortis) and confinement (per custodiam) ${ }^{29}$

In post-classical Roman law laesio enormis, i.e., injury beyond half constituted a peculiar contestability cause. Its core can be summed as follows. The

${ }^{21}$ Mayer-Maly, Th.: Pactum, Tausch und laesio enormis in den sog. leges Barbarorum. Zeitschrift der Savigny-Stiftung für rechtsgeschichte, Romanistische Abteilung 108. 1991. 213 233., 216.

${ }^{22}$ Babják 2011. 177.

${ }^{23}$ Mayer-Maly 1991. 217.

${ }^{24}$ Lex Baiuvariorum 16, 2.

${ }^{25}$ Lex Wisigothorum 5, 4, 3.

${ }^{26}$ Codex Euricianus 286.

${ }^{27}$ Babják 2011. 178.

${ }^{28}$ Cf. Levy, E.: Weströmisches Vulgarrecht. Das Obligationrecht. Weimar 1956. 25; Nótári $2011 \mathrm{~b} 175$.

${ }^{29}$ Babják 2011. 179. 
price (pretium) must be definite in money (certum), real (verum, not pretended), and-in Iustinianus's law-just (iustum, i.e., in proportion to value). The parties had the right to establish the price-however, in the $3^{\text {rd }}$ c. A.D., due to the crisis, Diocletianus maximised the price of certain things by decree (edictum de pretio rerum venalium-as a result the black market prospered); furthermore, with regard to immovable property he prescribed that the price should amount to at least half of the value of the property. In the absence thereof, when the buyer had suffered so-called injury beyond half (laesio enormis, laesio ultra dimidium), he could request that the purchase should be terminated and the thing returned; ${ }^{30}$ so, the seller had alternative authorisation (facultas alternativa) to either return the property or supplement the price to total value. ${ }^{31}$ Let us review whether this contestability cause appears in Lex Baiuvariorum.

"Venditionis haec forma servetur, ut seu res seu mancipium vel quodlibet genus animalium venditur, nemo propterea firmitatem venditionis inrumpat, quod dicat se vile pretio vendidisset. ${ }^{, 32}$ Accordingly, in sale the formalities required by law must be complied with so that-and here the thing to be sold in general and some movables, i.e., slaves and animals are listed as examples-nobody could contest the validity of the purchase by referring to the property having been sold at a very low price, which means that the law excludes reference to laesio enormis as contestability cause. Here Lex Baiuvariorum clearly builds on the Visigothic ru$1 \mathrm{e},{ }^{33}$ which states-and this provision applies to movable and immovable propertythat nobody can contest validity of purchase by referring to the property having been sold at a very low price. ${ }^{34}$ Consequently, it was not the Roman law regulation that the Bavarian lawmaker relied on; he worked towards keeping sale agreements in force to ensure security and predictability of the transaction. ${ }^{35}$

Prohibition to sell or donate a thing in action can be also considered an invalidity cause or limitation to ensure security of transaction ${ }^{36}$, which can be found in the title on things delivered for safekeeping and things lent (De commendatis et commodatis) rather than in the title on purchase: "Rem in contentione positam non liceat donare nec vendere". ${ }^{37}$ This rule was undoubtedly borrowed from Visigothic law, ${ }^{38}$ which stipulates that a thing in action shall not be sold or donated or transported anywhere. ${ }^{39}$

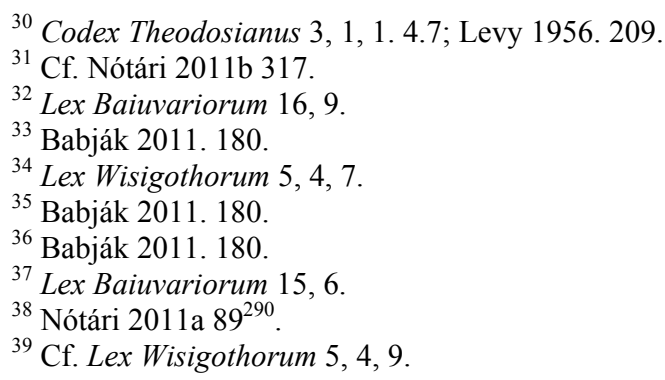


The law regulates validity of purchase entered into by slaves. ${ }^{40}$ When somebody bought something from a servus without the owner's knowledge or having approved of the transaction subsequently, the purchase price was returned to the buyer and the transaction was considered invalid; and when the object of the purchase no longer existed, the buyer had to return a similar thing to the holder of the slave who entered into purchase without any permit or commission: "Si quis a servo alieno aliquid conparaverit nesciente domino suo, si dominus firmam esse noluerit emptionem, reddatur pretium emptori, et emptio nihil habeat firmitatis; si ipsud non habet, cum simile reddat".

Consequently, this regulation sets out from the validity of the transaction, and invalidity must be reckoned with solely when it is aimed at by the will of the owner of the slave. It should be added that in this respect Lex Baiuvariorum definitely contrasts with Frankish rules since Lex Salica ordered to punish transactions entered into without the knowledge of the owner of the servus, ${ }^{42}$ and Lex Ribuaria excluded the owner's liability. ${ }^{43}$ Babják points out that in this issue it can be demonstrated that the Visigothic pattern prevailed in the Bavarian lex. ${ }^{44}$ So, it was presumed that the owner of the slave knew about the transaction, and as a general rule the law worked towards keeping the purchase in force, and somehow-by implied approval as the case may be-the owner of the servus had to take part in the transaction: in these cases Bavarians kept the interest of both contracting parties in view and made the risk of purchase entered into with an alien servus predictable. ${ }^{45}$

\section{Warranty issues and purchase of stolen things}

In what follows it is worth looking at the issues of warranty claims arising in relation to purchase. As part of that, first, implied warranty (liability for defects), then warranty of title and sale of alien and stolen things will be examined.

Already in Roman law the underlying principle of implied warranty was that the seller is obliged to take responsibility for hidden defects of the goodsand only for hidden defects since apparent defects must be noticed by a careful and prudent buyer (this is the principle of "caveat emptor"). Given the gradual development of the principles of implied warranty, this examination needs to fo-

${ }^{40}$ Nehlsen, H.: Die servi, ancillae und mancipia der Lex Baiuvariorum. Ein Beitrag zur Geschichte der Sklaverei in Bayern. In: Bellen, H.-Heinen, H. (Hrsg.): Fünfzig Jahre Forschungen zur antiken Sklaverei an der Mainzer Akademie, 1950-2000. Miszellanea zum Jubiläum. Stuttgart 2001. 505-521., 514.

${ }^{41}$ Lex Baiuvariorum 16, 3.

${ }^{42}$ Lex Salica 27, 33.

${ }^{43}$ Lex Ribuaria 77.

${ }^{44}$ Babják 2011. 183.

${ }^{45}$ Babják 2011. 184. 
cus on the rule which states that in praetor ${ }^{6}$ s law the seller was held liable for defects concealed by fraud (dolo malo) and for expressly promising (dicta et promissa) some characteristics of the goods or their being exempt from certain defects. The aedilis curulis, who was responsible for security of markets and acted as judge in market affairs, in his edictum prescribed-i.e., in this respect gave orders to make stipulatio-that in purchase of slaves and draught animals the seller shall take responsibility for certain defects (determined item by item) even if he does not know about them. This provision regulated purchase of draught animals and slaves, where the seller had to take objective responsibility. The buyer could cancel the contract by actio redhibitoria within six months, i.e., he could terminate it and the purchase price was returned to him by returning the goods. By actio quanti minoris he could bring an action within one year seeking reduction of the price to the extent that the thing was worth less for him. In this analysis it needs to be added that Romans calculated both deadlines as tempus utile; therefore, they took into account only the period of time when the buyer could actually bring an action, and calculated it from delivery of the thing. In post-classical law, practice extended these actions at law to any other object of the purchase. ${ }^{46}$ Let us now look at the rules of early medieval Bavarian law.

"Sed postquam factum est negotium, non sit mutatum, nisi forte vitium invenerit, quod ille venditor celavit, hoc est in mancipia aut in cavallo aut in qualecumque peculio, id est aut ceco ernioso cadivo aut leproso. In animalibus autem sunt vitia, quod aliquotiens celare potest venditor. Si autem venditor dixerit vitium, stet emptio, non potest mutare. Si autem non dixerit, mutare potest in illa die et in alia et tertia die. Et si plus de tribus noctibus habuerit, postea se non potest mutare, nisi forte eum invenire non poterit intra tres dies, tunc quando invenerit, recipiat, qui vitiatum vendidit. Aut si non vult recipere, iuret cum I sacramentale: 'quia vitium ibi nullum sciebam in illa die, quando negotium fecimus', et stet factum. "47 The text of the law sets forth that once it has been entered into the transaction can be contested only in the event that the buyer has found a defect in the goods that the seller has kept secret, i.e., concealed-and here the law clearly names movable property and material defects of the most important ones such as blindness, break, epilepsy and leprosy of slaves, horses and other draught animals. The defect must be hidden and concealed since the purchase cannot be attacked if the seller has informed the buyer on the defect. In case of concealment, the buyer has three days to assert his warranty claim: the claim applies-in addition to returning of the purchase price-to taking the goods back, i.e., redhibitio. This deadline will be extended only in the event that the buyer cannot find the seller in three days, and in this case the seller must ta-

\footnotetext{
${ }^{46}$ Nótári 2011 b 318. f.

${ }^{47}$ Lex Baiuvariorum 16, 9.
} 
ke the thing back at the time when the buyer finds him. The seller is not obliged to take the thing back-i.e., the transaction continues to be valid-when he takes an oath together with fellow oath-takers that at the time of the transaction he did not know about the defect claimed by the buyer.

Regarding this stipulation, Babják stresses that the redhibitio claim is unprecedented in German customary law and points out that the three days' deadline available to the buyer ${ }^{48}$ is strikingly short compared to the six months' deadline in Roman law; thirdly, he makes the apposite remark that Lex Baiuvariorum follows the classical legal tradition that is formulated also in the edictum of the aedilis curulis, more specifically that the seller is obliged to inform the buyer on the defects of slaves, horses and draught animals. ${ }^{49}$ (It needs to be added here that in our view the three days redhibitio deadline will be extended not only in the case when the buyer cannot contact the seller because the defect is revealed later-for example, due to giving into possession being separated from devolution of ownership-but also in the case when the buyer cannot find the seller within three days.) One of the formulas of Formulae Salicae Lindenbrogianae created in the monastery of St. Amand and brought to Bavaria by Arn, ${ }^{50}$ an abbot who became the bishop and then archbishop of Salzburg, ${ }^{51}$ required the seller to promise the buyer that the slave to be sold is not a fugitive or a cripple, is healthy and uninjured: ${ }^{52}$ "non fugitivum, non debilem, sed magis per omnia sanum atque incolomem." ${ }^{53}$ It is noteworthy that in Rome in accordance with the edictum of the aedilis curulis ${ }^{54}$ the seller is obliged to declare recte et palam

${ }^{48}$ See Lex Salica 37; Traditio Tegernseensis Nr. 1; Traditio Frisingensis Nr. 636.

${ }^{49}$ Babják 2011. 187.

${ }^{50}$ See Nótári, T.: Remarks on the Relation between the Breves Notitiae and the Notitia Arnonis. Studia Universitatis Babeş-Bolyai Iurisprudentia 2010/2.

${ }^{51}$ Cf. Stobbe, O.: Geschichte des deutschen Rechtsquellen, I. Braunschweig 1860. 253.

${ }^{52}$ Cf. Babják 2011. 189.

${ }^{53}$ Formulae Salicae Lindenbrogianae (MGH, Formulae, ed. K. Zeumer) 15. Venditio de servo. Magnifico in Christo fratri illo, emptore, igitur ego in Dei nomine. Constat me tibi vindidisse, et ita vindidi, tradidisse, et ita tradidi, hoc est servo iurisque mei nomino illo, non fugitivum, non debilem, sed magis per omnia sanum atque incolomem; unde accipi a te precium taxatum, in quo mihi bene conplacuit atque convenit, id est soledos tantos; in tali vero ratione, ut pro ipso precio ipsum iam dictum servum habeas, teneas atque possedeas, vel quicquid exinde facere volueris, liberam in omnibus habeas potastatem. Et si fuerit aliquis deinceps, si ego ipse aut ullus (quislibet) de heredibus vel quelibet ulla extranea persona, qui contra hanc vendicionem aliquam calumniam repeter conaverit, cui litem intulerit auro uncias tantas, argento libras tantas coactus exolvat, et haec venditio meis et me rogantibus bonorum hominum manibus roborata, quorum nomina vel signacula subter tenentur inserta, firma et stabilis permaneat, stipulatione subnexa (diunturno tempore maneat incolvulsa). Actum.

${ }^{54}$ See Jakab, É.: Stipulationes aediliciae. Szeged 1993; Kellékszavatosság és jótállás. In: Tanulmányok Benedek Ferenc tiszteletére. Pécs 1996. 113-123; Rabszolgavételek Rómában. In: Cséka Ervin Emlékkönyv. Szeged 1992. 247-259. 
whether the slave to be sold is ill, and, if he is, what his illness or defect is, whether he is a fugitive or is disposed to tramp and if he is encumbered by any noxa,${ }^{55}$ furthermore, regarding draught animals, he is obliged to inform the buyer whether the animals have any illness or defects. ${ }^{56}$

What makes this rule original and unique in the scope of German Volksrechts? As a general rule, Lex Baiuvariorum aims at keeping contracts in force and sets a quite narrow scope of exceptions-such as for example the opportunity to refer to vis ac metus ${ }^{57}$ and assert redhibitio ${ }^{58}$ within an extraordinarily short deadline. ${ }^{59}$ At the same time, the other folk law collections did not concede the right to cancel: e.g., the Langobardic Edictus Rothari contains the passage that states that in case a slave subsequently turns out to be a leper or epileptic, the seller shall be obliged to take an oath that he did not know about this defect, ${ }^{60}$ however, the law does not reveal the legal consequences of failure to take the oath, i.e., the seller's reticentia. Consequently, it can be established that it was only Lex Baiuvariorium from among German Volksrechts that adopted the implied warranty provisions of Roman law (specifically those of the aedilis's edictum)-albeit, with restrictions and in a narrower scope and deadline. ${ }^{61}$

In terms of both devolution of ownership and warranty of title, the sale of alien and stolen things is a highly important issue, which is discussed in Lex Baiuvariorum in details, in title nine on theft (De furto).

${ }^{55}$ Ulpianus, D. 21. 1. 1. 1. Aiunt aediles: Qui mancipia vendunt certiores faciant emptores, quid morbi vitive cuique sit, quis fugitivus errove sit noxave solutus non sit: eademque omnia, cum ea mancipia venibunt, palam recte pronuntianto. Quodsi mancipium adversus ea venisset, sive adversus quod dictum promissumve fuerit cum veniret, fuisset, quod eius praestari oportere dicetur: emptori omnibusque ad quos ea res pertinet iudicium dabimus, ut id mancipium redhibeatur. Si quid autem post venditionem traditionemque deterius emptoris opera familiae procuratorisve eius factum erit, sive quid ex eo post venditionem natum adquisitum fuerit, et si quid aliud in venditione ei accesserit, sive quid ex ea re fructus pervenerit ad emptorem, ut ea omnia restituat. item si quas accessiones ipse praestiterit, ut recipiat. Item si quod mancipium capitalem fraudem admiserit, mortis consciendae sibi causa quid fecerit, inve harenam depugnandi causa ad bestias intromissus fuerit, ea omnia in venditione pronuntianto: ex his enim causis iudicium dabimus. Hoc amplius si quis adversus ea sciens dolo malo vendidisse dicetur, iudicium dabimus.

${ }^{56}$ Ulpianus, D. 21. 1. 38 pr. Aediles aiunt: Qui iumenta vendunt, palam recte dicunto, quid in quoque eorum morbi vitique sit, utique optime ornata vendendi causa fuerint, ita emptoribus tradentur. Si quid ita factum non erit, de ornamentis restituendis iumentisve ornamentorum nomine redhibendis in diebus sexaginta, morbi autem vitive causa inemptis faciendis in sex mensibus, vel quo minoris cum venirent fuerint, in anno iudicium dabimus. Si iumenta paria simul venierint et alterum in ea causa fuerit, ut redhiberi debeat, iudicium dabimus, quo utrumque redhibeatur.

${ }^{57}$ Lex Baiuvariorum 16, 2.

${ }^{58}$ Lex Baiuvariorum 16, 9.

${ }^{59}$ Babják 2011. 190.

${ }^{60}$ Edictus Rothari 230.

${ }^{61}$ Babják 2011. 191. 
The question which arises when the owner of the stolen thing demands the goods back from the buyer is regulated by the law as follows. ${ }^{62}$ First of all, it prohibits purchase of stolen things ${ }^{63}$ and binds the buyer to find out if the thing has been stolen or not: "Ut nullus praesumat furtivam rem conparare infra provincia. Quod conparare voluerit, prius inquirat, si furtivum est, an non. ${ }^{, 64}$ It should be noted, however, that no reference can be found in the Bavarian lexcontrary to Lex Ribuaria ${ }^{65}$-whether there is any exact order of procedure of this inquiry. ${ }^{66}$ If it is proved-and here the law again draws on Visigothic regula$\operatorname{tion}^{67}$-that the buyer knew that the thing had been stolen, he shall be obliged to give the owner a thing with a value equal to the value of the stolen thing and pay twelve solidus to the treasury: "Si furtivum praesumpserit emere et exinde probatus fuerit, et scienter hoc fecit, tunc similem rem donet illi, cui pecunia conparavit, et in fisco pro fredo XII solidos sit culpabilis. ",68

How does the law regulate the issue when the buyer did not know that he bought a stolen thing? "Si quis de fure nesciens comparavit, requiret accepto spatio venditorem; quem si non poterit invenire, probet se cum sacramento et testibus innocentem. Et quod apud eum cognoscitur, ex medietate restituat, et furem quaerere non desistat." ${ }^{\prime 69}$ When the buyer did not know that he bought a stolen thing-the wording of the law reveals that the buyer must be considered identical with a thief-he had to try to find the seller, however, if his efforts brought no result, he could prove his innocence by taking an oath and witnesses. Furthermore, he had to return half of what had been found with him and keep searching for the thief. Babják claims that the linguistically quite obscure phrase "ex medietate restituat" covers content identical with the phrase "accepta pretii medietate, restituat" in Visigothic law ${ }^{70}$, i.e., the buyer was obliged to deliver the thing to the robbed owner in return for payment of half of the purchase price. ${ }^{71}$

However, sale of a stolen thing necessarily involved settlement of the legal relation between the buyer and the robbed owner as well as between the buyer and seller. Lex Baiuvariorum regulates this scope of issues as follows. "Si quis vendiderit res alienas sine voluntate domini sui, aut servum aut ancillam aut qualemcumque rem, ipsam per legem reddat et consimilem aliam reddat; si

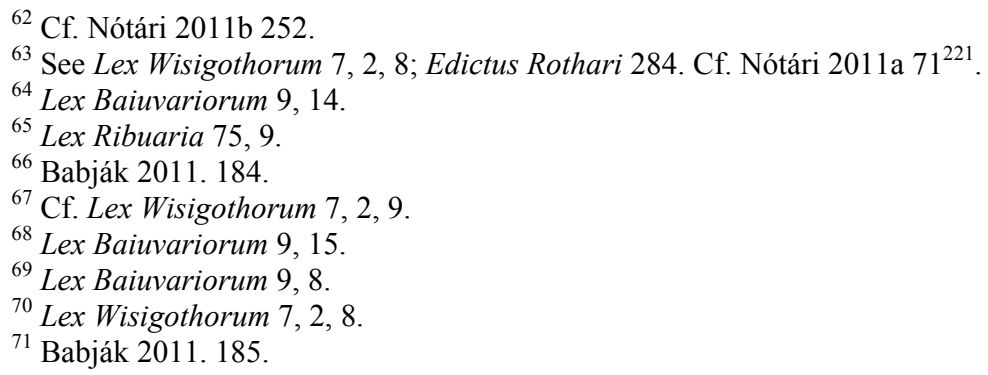


ipsam non potest invenire, duos consimiles reddat. "72 Accordingly, when somebody sells another person's thing in spite of the owner's will-and here the law stresses slaves as the most important objects of the transaction-he must return it and give a thing with similar value; and if the thing is no longer available, then he must give two things with similar value. Consequently, this provision covers compensation in duplum, which was adopted as a sanction of the Roman furtum nec manifestum ${ }^{73}$ through mediation of Visigothic law ${ }^{74}$ in Lex Baiuvariorum. ${ }^{75}$ A person who sells an alien thing-in addition to being bound to give the owner duplum-will be obliged to return the purchase price and reimburse the buyer the investments carried out by the buyer to increase the value of the thing: "Et domino his, qui alienam vendere presumpsit, duplum cogatur exolvere, nihilominus emptori, qui accepit pretium, redditurus. Et quicquid ad conparatae rei profectum studio suae utilitatis emptor adiecerit, a locorum iudicibus aestimetur, et ei qui laborasse cognoscitur, a venditore iuris alieni satisfactio iusta reddatur. " whom he has bought the stolen thing, he must deliver the thing to the owner in return for half of the purchase price, however, if he has found the venditor, then he can demand the total purchase price and his investments from him. Babják asserts that it cannot be ruled out that this regulation is some kind of reminiscence of the quadruple sanction (quadruplum) imposed on furtum manifestum known from pre-classical Roman law, and he underlines that in case the person selling the thing without permit cannot be found, the law prescribes spread of losses between the owner and the bona fide buyer of the thing. ${ }^{77}$

\section{Purchase safeguards}

The function of arra (or arrha) in Lex Baiuvariorum raises an interesting question. In accordance with the provisions set forth in the law, a person who has given arrha for a thing shall pay the purchase price agreed upon, and if he fails to appear in order to enter into the transaction on the day agreed upon and fails to ask for postponement, he will lose the arrha and shall pay the purchase price: "Qui arras dederit pro quacumque re, pretium cogatur implere, quod placuit emptori. Et si non accurrerit ad diem constitutum, vel antea non rogaverit ad placitum ampliorem, si hoc neglexerit facere: tunc perdat arras et pretium, quod de-

\footnotetext{
${ }^{72}$ Lex Baiuvariorum 16, 1.

${ }^{73}$ See 2011 b 339.

${ }^{74}$ Lex Wisigothorum 5, 4, 8.

${ }^{75}$ Babják 2011. 186.

${ }^{76}$ Lex Baiuvariorum 16, 4.

${ }^{77}$ Babják 2011. 187.
} 
buit, impleat. ${ }^{, 78}$ The prefiguration of this rule is a passage from the Visigothic Codex Euricianus quite difficult to interpret, ${ }^{79}$ although, as Babják finds, a coherent rule was developed from it by the makers of the Bavarian lex. ${ }^{80}$

Another provision of the law regarding transaction witnesses gets closer to the function of arrha. "Si quis testem habuerit per aurem tractum de qualibet causa finita ratione, et hoc confirmant per testes; post haec non debet repetire nec inquietare illum, a quo finivit rationem suam. Et si voluerit, per testes defendat se; ille testis testificet sicut scit, unde per testem per aurem tractus fuit, et hoc per sacramentum confirmet. ... Si autem testes per autem tractus fuerit de conpositione finienda vel propter arras, qui donat quasi pro pignus qualecumque re, usque dum solvat debitum et pignus recipiat: illum testem nemo repellat nec potest, sed consentiat..." ${ }^{, 81}$ Accordingly, if concerning any transaction entered into a person has a witness whose ears he has pulled, after that he cannot demand anything back from the person with whom he has entered into the transaction. If the contracting party wants, he can refer to a witness, who is obliged to testify entering into the transaction under oath. If the witness's ears have been pulled concerning either the determination of redemption or arra, i.e, earnest-money, given as pledge until the debt is paid and the pledge is returned, the witness's testimony cannot be ignored. Babják stresses that this passage is an ex asse rule of Bavarian customary law rather than an adopted Visigothic or other pattern and that the pledge function of arra is basically different from the Visigothic rule that clearly differentiates earnest-money from pledged collateral as pledge must be returned and arrha is earnest-money for the debt to be discharged: everyday Bavarian legal practice handled arrha as pledge. ${ }^{82}$ (It should be noted that application of pignus, i.e., wadium-mutually between the parties in dispute-is mentioned in Traditio Frisingensis ${ }^{83}$ and in Traditio Pataviensis ${ }^{84}$ as well. ${ }^{85}$ ) On the other hand, the Bavarian lex does not regulate certain questions, such as for example the character, scope of application of the things that can be delivered as the object of arrha or the connection between the transaction to be secured and the value of arrha. ${ }^{86}$

It is worth giving a brief survey of the scope of application and main features of arrha as developed in Roman law in order to determine the important

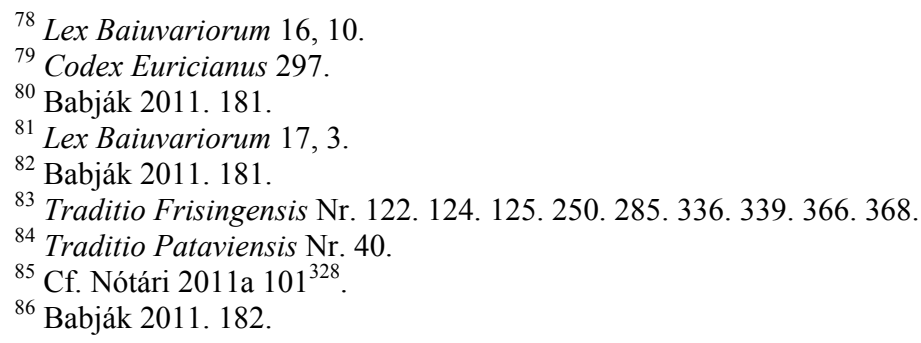


characteristics of this institution in early medieval Bavarian law more clearly. In Roman law earnest-money (arrha) is the value that one party gives to the other as a sign of entering into contract and as contractual safeguard. In the classical age, giving earnest-money served as a token of entering into purchase, and in purchase concluded by arrangement earnest-money confirmed its conclusion only (arrha confirmatoria). In the post-classical age, upon Greek impact, earnest-money served as contractual safeguard; in other words, it assumed a punitive character (arrha poenalis). This can be called forfeit money too, since it was the right to cancel the contract that the party reserved by sacrificing this amount. In this type, the non-performing party lost the earnest-money given and had to return double the amount of the earnest-money received, thereby earnest-money became obligation safeguards, more specifically security for the debtor's willingness to pay. In case of performance, the earnest-money had to be set off or returned-the act of giving earnest-money did not exclude assertion of any further compensation claims. ${ }^{87}$

In Bavarian law, by delivering arrha the party assumes obligation to pay the purchase price agreed upon on the day determined, failing which-and in the absence of a new term of payment set-he will lose the arrha handed over, however, he shall pay the purchase price. It is questionable whether the buyer was given the object of purchase upon delivery of the arrha or not, or could take it later, and if delivery of the arrha obliged only the buyer to pay the purchase price, or the seller was also bound by obligation not to sell the thing to anybody else during the period between conclusion of the contract and delivery of the thing. The regulation of arrha in Bavarian law is different from the solution in Roman law: it brings the function of arrha closer to right of pledge. ${ }^{88}$

\section{Other contracts in Lex Baiuvariorum}

It needs to be added that rules of purchase should be applied mutatis mutandis to exchange (of goods) too, for-just as Langobardic ${ }^{89}$ and Visigothic ${ }^{90}$ law or post-classical imperial decrees in Roman law ${ }^{91}$-Lex Baiuvariorum stipulates that exchange, i.e., cambias shall have the same force as purchase: "Commutatio, hoc est quod 'cambias', talem qualis emptio habeat firmitatem". ${ }^{92}$ This rule was borrowed word for word by the Bavarian lex from Visigothic law. ${ }^{93}$

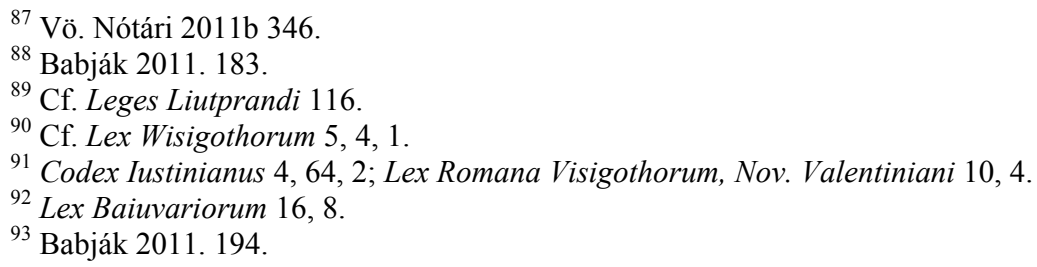


Apart from purchase, Lex Baiuvariorum deals with other contracts in less detail in title fifteen on things delivered for safekeeping and things lent (De commendatis et commodatis). The law defines two forms of safekeeping: safekeeping against valuable consideration and safekeeping free of charge. "Si quis cavallum aut quolibet animalium genus ad custodiendum mercede placita commendaverit: si perierit, eiusdem meriti ille qui commendata suscepit, exolvat, si tamen mercede fuerit pro custodia consecutus. Quodsi etiam nulla placita mercede susciperat, mortua esse probaverit: nec ille mercedem requirat, nec ab illo aliquid requiratur; tamen ratione, ut praebeat sacramenta ille qui commendata susciperat, quod non, per suam culpam neque per neglegentiam mortua consumpta sint, et reddat corio. Eadem et de commendatis forma servetur." 94 When some kind of animal is handed over for safekeeping against a determined fee and the animal perishes, it shall be compensated for by an animal with identical value if the safekeeping fee has been paid already. When the thing is received for safekeeping against no fee, i.e., free of charge and it perishes, then the receiving party cannot demand any fee subsequently and cannot be demanded to pay compensation if he proves by an oath that it was not due to his culpa or neglegentia that the animal perished; however, he must return the skin of the animal-this latter provision is a general rule in German folk laws. ${ }^{95}$ In the case of loan, the law prescribes application of the same rule. Concerning this provision it can be established that the Bavarian lex draws on Visigothic laws, Lex Wisigothorum $^{96}$ and Codex Euricianus ${ }^{97}$.

Similarly, the following rule is based on Visigothic law ${ }^{98}$. "Si cui aurum vel argentum vel ornamenta vel quaecumque species fuerint commendatae, sive custodiendae traditae sint, sive vendendae, et in domo ipsius cum rebus ipsius forsitan fuerint incendio concrematae, una cum testibus, qui commendata susciperat, praebeat sacramenta, nihil exinde suis profuisse conpendiis, et nihil cogatur exolvere, excepto auro et argento, quod ardere non potuit." 99 When a movable thing is handed over to a person-here the lawmaker refers to gold, silver and jewellery as examples; so, the provision might probably apply to valuable things-for safekeeping (for the purposes of sale, i.e., on consignment for sale as the case may be), and this thing is destroyed in fire in the house of the safekeeping party together with his own things, such person shall prove by an oath that he received no gains from it and must return only the gold and silver that could not burn. Thus, in this passage the law regulates the issue of consignment

\footnotetext{
${ }^{94}$ Lex Baiuvariorum 15, 1.

${ }^{95}$ Cf. Nótári 2011 a $89^{285}$.

${ }^{96}$ Cf. Lex Wisigothorum 5, 5, 1 .

${ }^{97}$ Cf. Lex Euriciana 278.

${ }^{98} \mathrm{Cf}$. Lex Wisigothorum 5, 5, 3.

${ }^{99}$ Lex Baiuvariorum 15, 2.
} 
for sale, on the one hand, and, serves security of safekeeping of valuable movable things, on the other; it is not by chance that it stresses precious metals handed over for safekeeping. However, the law elaborates the opportunities of the case, drawing on Visigothic law. ${ }^{100}$ If in a fire somebody steals the thing handed over for safekeeping and the thief can be found, he shall reimburse the quadruple of the value of the thing stolen ${ }^{101}$-just as in Roman law in case of furtum manifestum. ${ }^{102}$ The person from whom the thing entrusted to him has been stolen shall be provided with sufficient time for finding the thing and when he has found it, the party giving the thing into safekeeping will get back only his own thing, however, he will be entitled to conpositio due to theft. ${ }^{103}$ When the thief has not been found, the owner will get only half of the value of the thing stolen, in other words, the law prescribes spread of losses between the parties. ${ }^{104}$

In summary it can be stated that from among German Volksrechts it is Lex Baiuvariorum that contains the greatest number of contractual provisions-and the most flexible provisions maximally meeting requirements of practice at that. Their prime aim indicated expressis verbis in the code is to keep concluded contracts in force and preserve security of transactions. These Bavarian statutory provisions mostly draw on Visigothic patterns, however, lawmakers did not copy them slavishly, they modified them in accordance with their own experience. ${ }^{105}$

${ }^{100}$ Cf. Lex Wisigothorum 5, 5, 3.

${ }^{101}$ Lex Baiuvariorum 15, 3. Si quis forte, dum domum flamma consumpsit, se quasi auxilium adlaturus ingesserit et aliquod forte rapuerit, dominus domui diligenter inquirat. Et si eum potuerit invenire, ille qui rapuerat, in quadruplum rapta restituat. Et si de commendatis rebus apud direptorem aliquid forte reppererit, domino restituere non moretur.

${ }^{102}$ See Nótári 2011 b 339.

${ }^{103}$ Lex Baiuvariorum 15, 4. Si vero quae commendata fuerant, furto probantur ablata, ei qui commendata perdiderat, spatium tribuatur, donec furem sua investigatione perquirat. Et si eum invenerit, commendatori res proprias tantummodo reformare procuret; compositio vero furti ad eum, qui habuit commendata, pertineat.

${ }^{104}$ Lex Baiuvariorum 15, 5. Et si fur non fuerit infra statutum tempus inventus, medietas rerum commendatarum domino suscipiente reddatur, damnum vero medio utrumque sustineat.

${ }^{105}$ Babják 2011. 193-195. 
Др Тамаш Нойари, ванредни йрофесор

Универзитетеи у Сеіеедину

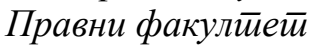

\section{Уговорно право у зборнику Lex Baiuvariorum ${ }^{106}$}

Сажетйак: Циљ овоі̄ рада је анализа одредаба о уїоворима у зборнику Lex Baiuvariorum, ${ }^{107}$ који йредстиављь йисано баварско народно йраво (Volksrecht), а насйао је између 737 и 743. іодине. У оквиру ове анализе, йрво

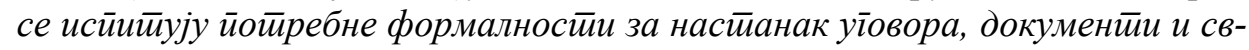
едочансиива (I.); заииим ирравила о неважносиии (II.); о коришћеним іараниијама и о куйовини украдених стивари (III.); реїулисање уіоворної обезбеђења (IV.); а, најзад, и друйи конйракӣи овоі зборника (V.). У йойледу sedes materiaе указује се на йо, да су иравила која се односе на размену добара смешиенена ирвенстивено йод два наслова зборника: йод наслов једанаести (De venditionibus) и йод наслов девети (De furto) - йод овим йоследним насловом, излажу се иравила о йродаји украдених сиивари, $\bar{u} j .$, досйуйне $\bar{l}-$ араниијске йужбе, које са једне сииране йосмайрају однос између йокраденоі лииа и лица које је куйило сиивар bonaе fidei, а са друіе сииране између ирродавия и куйца. Одређена иравила, као шито је на йример, ирравило о забрани иродаје сиорних сиивари, моіуу се наћи йод иееинаесииим насловом (De commendatis et commodatis).

Кључне речи: Lex Baiuvariorum, баварско народно йраво - Volksrecht, баварско уїоворно йраво

${ }^{106}$ Овај рад је настао у оквиру пројекта, Nr. 4.2.2.B-10/1-2010-0015 „Identitäten: Kulturen und Minderheiten im Donauraum“.

${ }^{107}$ O Lex Baiuvariorum видети, Nótári, T.: Lex Baiuvariorum-A bajorok törvénye. Szeged 2011. (Nótári 2011a); Römischrechtliche Elemente im Prolog der Lex Baiuvariorum. Annales Universitatis Scientiarum Budapestinensis de Rolando Eötvös nominatae, Sectio Iuridica 50. 2009. 419-429; Bavarian Historiography in Early Medieval Salzburg. Passau 2010; Personal Status and Social Structure in Early Medieval Bavaria. Acta Juridica Hungarica 50. 2009/1. 85110; An Early-Medieval „, Show Trial”-Tasilo III's Dethronement. In: Beck Varela, L.-Gutiérrez Vega, P.-Spinosa, A. (eds): Crossing Legal Cultures. München 2009. 141-158. 